\title{
Using hooked-end fibres on high performance steel fibre reinforced concrete
}

\author{
Y. Gündüz ${ }^{1}$, E. Taşkan ${ }^{1} \&$ Y. Şahin ${ }^{2}$ \\ ${ }^{1}$ Institute of Science and Technology, Bozok University, Turkey \\ ${ }^{2}$ Department of Civil Engineering, Bozok University, Turkey
}

\begin{abstract}
Concrete is a brittle material. Numerous studies were performed on increasing the ductility of concrete. Steel fibres were widely used in concrete because of its advantages on the toughness, ductility and strength properties of steel fibre reinforced concretes (SFRCs). Owing to improving the bond properties between fibre and matrix, hooked-ended steel fibres are mostly preferred in SFRCs. In this study, the effect of type of hooked-end fibres on a high performance concrete (HPC) were investigated by an experimental research. Three different hookedended steel fibres were added in four different volume fraction in a high performance concrete. Fracture energies and mechanical strengths of concretes were determined by flexural tensile strength tests. Test results showed that there were significance effects of types of hooked-end on post cracking behaviour and fracture energy of high performance steel fibre reinforced concretes (HPSFRCs). Keywords: high performance concrete, steel fibre, ductility, fracture energy.
\end{abstract}

\section{Introduction}

Concrete is a widely used material in constructions and has high compressive strength. It is tensile strength is about $8-12 \%$ of it is compressive strength. Steel bars; diameters usually changing between $6-32 \mathrm{~mm}$, were used in reinforced concrete elements. Fibre reinforcement is generally randomly distributed in the whole element, also it can be used in a part of the elements [1]. Steel Fibre reinforced concretes (SFRCs) were widely used in civil engineering structures; industrial floors, airport and highway pavements, tunnels, bridges, hydraulic structures, earthquake and impact resistant structures, etc. [3]. The concrete properties benefited by fibre reinforcement. Energy absorption capacity, load 
carrying capacity, ductility, toughness, fracture energy, tensile and shear strengths and impact resistance are marginally increased by using fibres.

High strength concrete (HSC) is defined as concrete that meets special performance which cannot be achieved by conventional concrete. Also high performance concrete (HPC) is a concrete mixture, which provides high strength and high durability when compared to conventional concrete. HPC is an economical solution for many structural cases to provide adequate durability and is particularly advantageous in compression elements [1,3-5]. Concrete has some disadvantages like low tensile strength, low ductility and low toughness. These disadvantages getting more significant as increasing of concrete compressive strength. The increment in the mechanical properties of the SFRC will depend primarily on the type of the fibres, their geometrical properties and the amount of fibres added [6]. The main role of dispersed fibres is to control the opening and developing of cracks by bridging the faces of crack [7]. The success of bridging effect generally depends on pull-out mechanisms. Pull-out strength depends on not only bond quality between fibre and matrix but also fibre properties such as hooked-ends and strength. To improve pull-out resistance mechanically deformed fibres are more effective than straight fibres [8-11].

In this study, effect of type of hooked-end on workability, compressive strength, modulus of elasticity, splitting tensile and flexural strengths, and also fracture parameters of concrete were investigated by an experimental study. Three different steel fibres having different hooked-ends were added in very high strength concrete mixture including silica fume. Test results showed that there were significance effects of types of hooked-end on post cracking behaviour and fracture parameters of SFRCs.

\section{Materials and mix proportions}

\subsection{Materials}

\subsubsection{Cement}

CEM I $42.5 \mathrm{R}$ type cement was used. Specific gravity and fineness (Blaine), of cement were $3.11 \mathrm{~g} / \mathrm{cm}^{3}$ and $3320 \mathrm{~cm}^{2} / \mathrm{g}$, respectively. Chemical composition of cement are given in Table 1 .

Table 1: $\quad$ Chemical composition of cement (\%).

\begin{tabular}{|l|l|l|c|c|c|c|c|c|c|}
\hline $\mathrm{CaO}$ & $\mathrm{CI}^{-}$ & $\mathrm{SO}_{3}$ & $\mathrm{MgO}$ & $\mathrm{Na}_{2} \mathrm{O}$ & $\mathrm{K}_{2} \mathrm{O}$ & $\mathrm{SiO}_{2}$ & $\mathrm{Al}_{2} \mathrm{O}_{3}$ & $\mathrm{Fe}_{2} \mathrm{O}_{3}$ & L.O.I \\
\hline 62.30 & 0.01 & 3.25 & 2.60 & 0.23 & 1.11 & 18.70 & 5.48 & 3.01 & 2.57 \\
\hline
\end{tabular}

\subsubsection{Aggregates}

In the aggregate mixture, crushed sand and crushed stone I and II were used as $48 \%, 27 \%$ and $\% 25$, respectively. Density and water absorption tests were conducted on aggregates in accordance with TS EN 1097-6. Densities and particle size distributions of aggregates are given in Table 2. 
Table 2: $\quad$ Physical properties and particle size distributions of aggregates.

\begin{tabular}{|l|c|c|c|c|c|c|c|c|c|}
\hline \multirow{2}{*}{ Aggregate } & \multirow{2}{*}{$\begin{array}{c}\text { Density } \\
\left(\mathrm{g} / \mathrm{cm}^{3}\right)\end{array}$} & \multicolumn{7}{|c|}{ Sieve size, mm - \% passing } \\
\cline { 3 - 10 } & 0.25 & 0.5 & 1 & 2 & 4 & 8 & 16 & 32 \\
\hline $\begin{array}{l}\text { Crushed } \\
\text { sand }\end{array}$ & 2.63 & 22.5 & 32.6 & 48.5 & 63.0 & 90.1 & 100 & 100 & 100 \\
\hline $\begin{array}{l}\text { Crushed } \\
\text { stone I }\end{array}$ & 2.70 & 0.3 & 0.3 & 0.3 & 0.3 & 3.3 & 74.5 & 100 & 100 \\
\hline $\begin{array}{l}\text { Crushed } \\
\text { stone II }\end{array}$ & 2.71 & 0.2 & 0.2 & 0.2 & 0.2 & 0.4 & 0.8 & 14.8 & 100 \\
\hline
\end{tabular}

\subsubsection{Chemical admixture}

A new generation polycarboxylate ether (PCE) based superplasticizer was used in mixtures.

\subsubsection{Mineral admixture}

Silica fume was used as mineral admixtures in mixtures. Density and specific surface of silica fume were $2.23 \mathrm{~g} / \mathrm{cm}^{3}$ and $2336 \mathrm{~cm}^{2} / \mathrm{g}$, respectively. Chemical composition of silica fume is given in Table 3 .

Table 3: $\quad$ Chemical composition of silica fume (\%).

\begin{tabular}{|c|c|c|c|c|c|c|}
\hline $\mathrm{CaO}$ & $\mathrm{SO}_{3}$ & $\mathrm{MgO}$ & $\mathrm{SiO}_{2}$ & $\mathrm{Al}_{2} \mathrm{O}_{3}$ & $\mathrm{Fe}_{2} \mathrm{O}_{3}$ & L.O.I \\
\hline 0.8 & 1.34 & 1.47 & 85.35 & 1.42 & 2.39 & 3.4 \\
\hline
\end{tabular}

\subsubsection{Steel fibres}

In this study, three different steel fibres which have same length and aspect ratio and different hooked-end, were used. The properties of fibres were given in Table 4 and photo of fibres was given in Figure 1. Commercially available fibres were used and codes were selected as same as commercial names.

Table 4: $\quad$ Properties of fibres.

\begin{tabular}{|l|c|c|c|c|c|}
\hline Code & $\begin{array}{c}\text { Length, } 1 \\
(\mathrm{~mm})\end{array}$ & $\begin{array}{c}\text { Diameter, } \\
\mathrm{d}(\mathrm{mm})\end{array}$ & $\begin{array}{c}\text { Aspect } \\
\text { ratio, }(\mathrm{l} / \mathrm{d})\end{array}$ & $\begin{array}{c}\text { Density, } \\
\left(\mathrm{g} / \mathrm{cm}^{3}\right)\end{array}$ & $\begin{array}{c}\text { Tensile } \\
\text { strength, } \\
\mathrm{f}_{\text {su }}(\mathrm{MPa})\end{array}$ \\
\hline 3D65/60 BN & 60 & 0.90 & 65 & 7.85 & 1160 \\
\hline 4D65/60 BG & 60 & 0.90 & 65 & 7.85 & 1500 \\
\hline 5D65/60 BG & 60 & 0.90 & 65 & 7.85 & 2300 \\
\hline
\end{tabular}




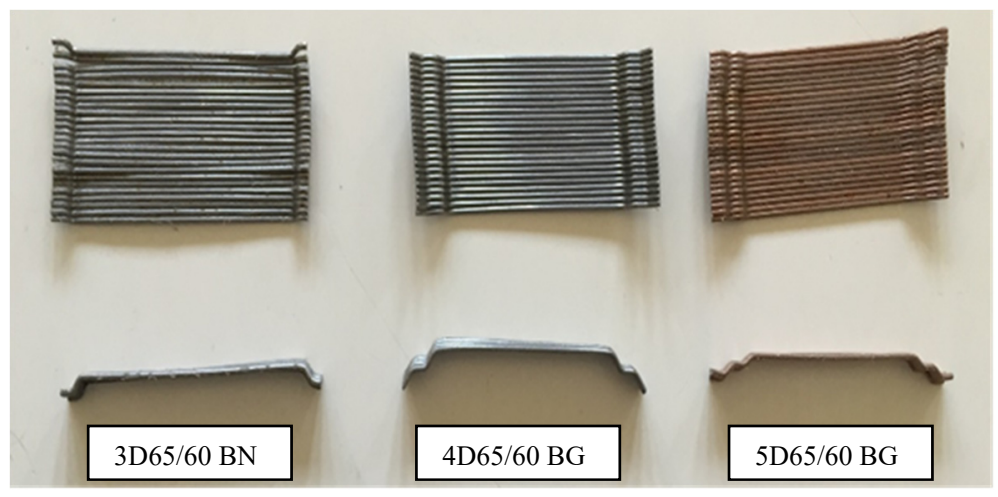

Figure 1: Steel fibres.

\subsection{Mixture proportions}

A concrete mixture with a water/(cement + silica fume $)$ ratio of 0.30 was produced and steel fibres added in these mixtures at 15,30, 45 and $60 \mathrm{~kg} / \mathrm{m}^{3}$. Mixture proportions of ingredients are given in Table 5 .

Table 5: $\quad$ Mixture proportions $\left(\mathrm{kg} / \mathrm{m}^{3}\right)$.

\begin{tabular}{|c|c|c|c|c|c|c|c|}
\hline $\begin{array}{l}\text { Fibre } \\
\text { content }\end{array}$ & Cement & Water & $\begin{array}{c}\text { Crush. } \\
\text { sand }\end{array}$ & $\begin{array}{l}\text { Crush. } \\
\text { stone I }\end{array}$ & $\begin{array}{l}\text { Crush. } \\
\text { stone II }\end{array}$ & $\begin{array}{l}\text { Super - } \\
\text { plasticizer }\end{array}$ & $\begin{array}{l}\text { Silica } \\
\text { fume }\end{array}$ \\
\hline 0 & \multirow{5}{*}{450} & \multirow{5}{*}{149} & 847 & 489 & 455 & \multirow{5}{*}{5.4} & \multirow{5}{*}{45} \\
\hline 15 & & & 845 & 488 & 454 & & \\
\hline 30 & & & 843 & 487 & 452 & & \\
\hline 45 & & & 840 & 485 & 451 & & \\
\hline 60 & & & 838 & 484 & 450 & & \\
\hline
\end{tabular}

\section{Methods}

\subsection{Testing}

The flexural tensile strength test was performed on $150 \times 150 \times 550 \mathrm{~mm}^{3}$ prismatic notched-specimens by using the beam method according to EN 14651 standard at which load is applied at one third points of the specimen. The notched-specimens with a depth of $25 \mathrm{~mm}$ and width of $3 \mathrm{~mm}$ were tested by using a closed loop deflection-controlled loading frame of $250 \mathrm{kN}$ capacity and loading rate was 0.2 $\mathrm{mm} / \mathrm{min}$. Test setup is given in Fig. 2. Load and the mid-span deflection of the beams were simultaneously recorded and, load-deflection curves for each specimen were also obtained graphically during the test. 

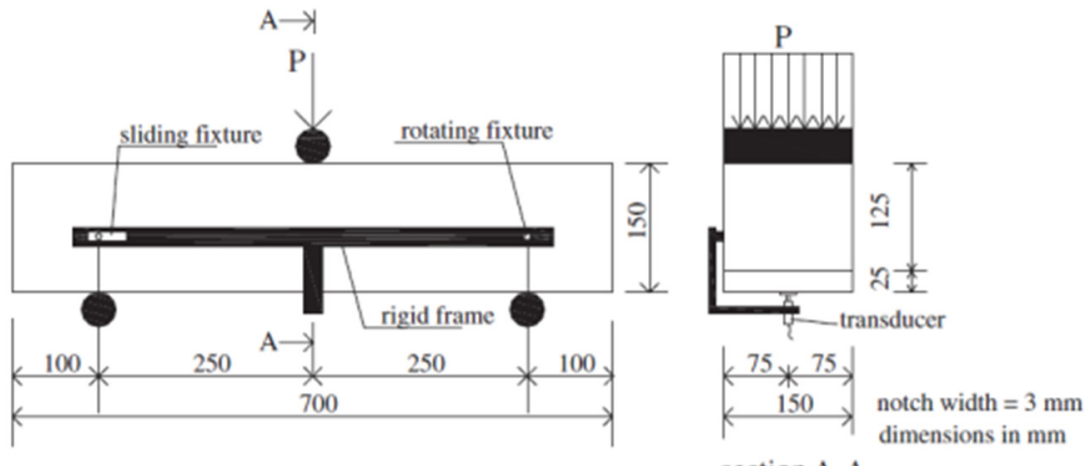

Figure 2: Flexural test setup.

\subsection{Calculations}

\subsubsection{Limit of proportionality (LOP)}

$$
f_{c t, L}^{f}=\frac{3 F_{L} l}{2 b h_{s p}^{2}}
$$

where, $F_{L}$ is the load corresponding to the LOP, and $1, \mathrm{~b}$ and $\mathrm{h}_{\mathrm{sp}}$ are span length, width of the specimen and distance between the tip of the notch and the top of the specimen, respectively.

\subsubsection{Fracture parameters}

The fracture energy, $\mathrm{G}_{\mathrm{F}}$, was calculated by following equation (2) given RILEM TC-50 FMC [12],

$$
G_{F}=\frac{W_{0}+m\left(1-k^{2}\right) \rho \delta}{b(h-a)}
$$

where $\mathrm{W}_{0}$ is the energy represented by the area under the load-deflection curve, $\mathrm{m}$ is the mass of the specimen, $\rho$ is the acceleration due to gravity, $\delta$ maximum deflection at final fracture (in this study, it is $5 \mathrm{~mm}$ ), b is the beam thickness, $\mathrm{h}$ and a are the depth of the beam and notch, respectively.

The characteristic length $\left(\mathrm{l}_{\mathrm{ch}}\right)$ is proposed by Hillerborg et al. [13], and defined as the ratio;

$$
l_{c h}=\frac{G_{F} \cdot E}{f_{t}^{2}}
$$

where $E$ is the modulus of elasticity and $f_{t}$ is the tensile strength. In this study, splitting tensile strength, $\mathrm{f}_{\mathrm{st}}$ was used instead of $\mathrm{f}_{\mathrm{t}}$. 


\section{Results}

\subsection{Fresh concrete properties}

The properties of fresh concrete and the results of mechanical tests are given in Table 6 . Concrete and medium temperatures were kept $22 \pm 2^{\circ} \mathrm{C}$ during casting of concretes.

Table 6: Fresh concrete tests.

\begin{tabular}{|l|c|c|c|c|c|}
\hline $\begin{array}{l}\text { Mixture } \\
\text { Code }\end{array}$ & $\begin{array}{c}\text { Slump } \\
\mathrm{cm}\end{array}$ & $\begin{array}{c}\text { Vebe } \\
\mathrm{sn}\end{array}$ & $\begin{array}{c}\text { Density } \\
\mathrm{kg} / \mathrm{m}^{3}\end{array}$ & $\begin{array}{c}\text { Concrete } \\
\text { temp. }{ }^{\circ} \mathrm{C}\end{array}$ & $\begin{array}{c}\text { Medium } \\
\text { temp. }{ }^{\circ} \mathrm{C}\end{array}$ \\
\hline Reference & 18 & 3 & 2408 & 22.2 & 23.7 \\
\hline 3DV15 & 18 & 2.7 & 2434 & 23.2 & 24.8 \\
\hline 3DV30 & 16 & 3.8 & 2434 & 22.4 & 24.8 \\
\hline 3DV45 & 14 & 5 & 2438 & 22.9 & 24.8 \\
\hline 3DV60 & 12 & 7.5 & 2446 & 22.3 & 23.8 \\
\hline 4DV15 & 18 & 3 & 2434 & 23.0 & 24.8 \\
\hline 4DV30 & 16 & 4 & 2440 & 23.0 & 25.0 \\
\hline 4DV45 & 13 & 6.5 & 2448 & 21.8 & 24.6 \\
\hline 4DV60 & 12 & 9.5 & 2448 & 22.6 & 24.0 \\
\hline 5DV15 & 17 & 3 & 2424 & 22.7 & 23.9 \\
\hline 5DV30 & 16 & 4.5 & 2440 & 22.2 & 23.3 \\
\hline 5DV45 & 11.5 & 7.5 & 2448 & 22.0 & 23.9 \\
\hline 5DV60 & 11 & 9 & 2452 & 22.3 & 23.8 \\
\hline
\end{tabular}

Slump and Vebe tests results of mixtures are shown in Figure 3. Slump values were decreased with increasing fibre content. However Vebe times were increased with increasing of fibre content. Vebe test is more suggested for assessment of workability of SFRC.
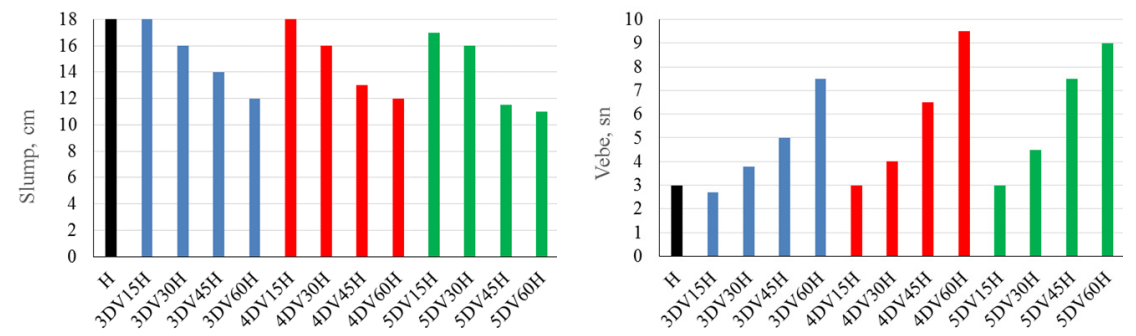

Figure 3: $\quad$ Slump and Vebe values of mixtures. 


\subsection{Mechanical properties}

In order to obtain and compare the mechanical properties, the compressive strength, modulus of elasticity and splitting tensile tests were performed on hardened concretes in accordance with the standards EN 12390-3, ASTM C 469 and EN 12390-6. Results of mechanical properties are given in Table 7. It could not be seen any significant effect of fiber content on the compressive strength and modulus of elasticity (Figure 4).

Splitting tensile strength results are shown in Fig. 5. Splitting tensile strengths were increased with increasing of fiber content. Amount of increments are given above the bars as percentage. $3 \mathrm{D}, 4 \mathrm{D}$, and $5 \mathrm{D}$ hooked ends increased the splitting tensile strengths as average of $28.8 \%, 26.8 \%$ and $29.9 \%$, respectively.

Table 7: Results of mechanical properties.

\begin{tabular}{|l|c|c|c|c|c|c|}
\hline $\begin{array}{l}\text { Mixture } \\
\text { Code }\end{array}$ & $\begin{array}{c}\text { Compr. } \\
\text { strength } \\
\text { (MPa) }\end{array}$ & $\begin{array}{c}\text { Modulus } \\
\text { of } \\
\text { elasticity } \\
(\mathrm{GPa})\end{array}$ & $\begin{array}{c}\text { Splitting } \\
\text { tensile } \\
\text { strength } \\
(\mathrm{MPa})\end{array}$ & $\begin{array}{c}\text { LOP } \\
(\mathrm{MPa})\end{array}$ & $\begin{array}{c}\text { Fracture } \\
\text { energy } \\
(\mathrm{N} / \mathrm{m})\end{array}$ & $\begin{array}{c}\text { Charac. } \\
\text { length } \\
(\mathrm{mm})\end{array}$ \\
\hline Reference & 83.0 & 41.5 & 4.11 & 3.67 & - & - \\
\hline 3DV15 & 80.4 & 40.8 & 4.88 & 3.31 & $496^{*}$ & $0.83^{*}$ \\
\hline 3DV30 & 83.0 & 39.6 & 5.29 & 4.56 & 1311 & 1.87 \\
\hline 3DV45 & 80.7 & 40.9 & 5.49 & 4.60 & 1553 & 1.99 \\
\hline 3DV60 & 84.0 & 40.7 & 5.54 & 4.31 & 2215 & 2.89 \\
\hline 4DV15 & 83.0 & 41.1 & 4.90 & 3.93 & $550^{* *}$ & $0.9{ }^{* *}$ \\
\hline 4DV30 & 85.5 & 40.5 & 5.28 & 4.24 & 1283 & 1.84 \\
\hline 4DV45 & 82.5 & 41.5 & 5.43 & 4.26 & 1582 & 2.15 \\
\hline 4DV60 & 81.8 & 39.3 & 5.26 & 4.43 & 2386 & 3.30 \\
\hline 5DV15 & 84.3 & 41.3 & 4.92 & 3.95 & 1521 & 2.51 \\
\hline 5DV30 & 82.5 & 39.3 & 5.32 & 3.87 & 2108 & 2.98 \\
\hline 5DV45 & 83.3 & 40.6 & 5.45 & 4.19 & 2137 & 2.88 \\
\hline 5DV60 & 79.9 & 40.3 & 5.69 & 4.56 & 3292 & 4.07 \\
\hline
\end{tabular}

*Specimens were broken at average $1.77 \mathrm{~mm}$.

** Specimens were broken at average $3.5 \mathrm{~mm}$.
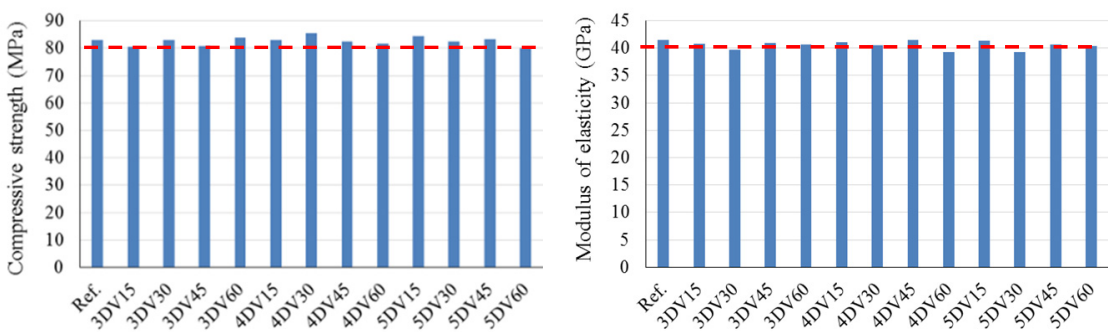

Figure 4: Compressive strength and modulus of elasticity of concretes. 
272 High Performance and Optimum Design of Structures and Materials II

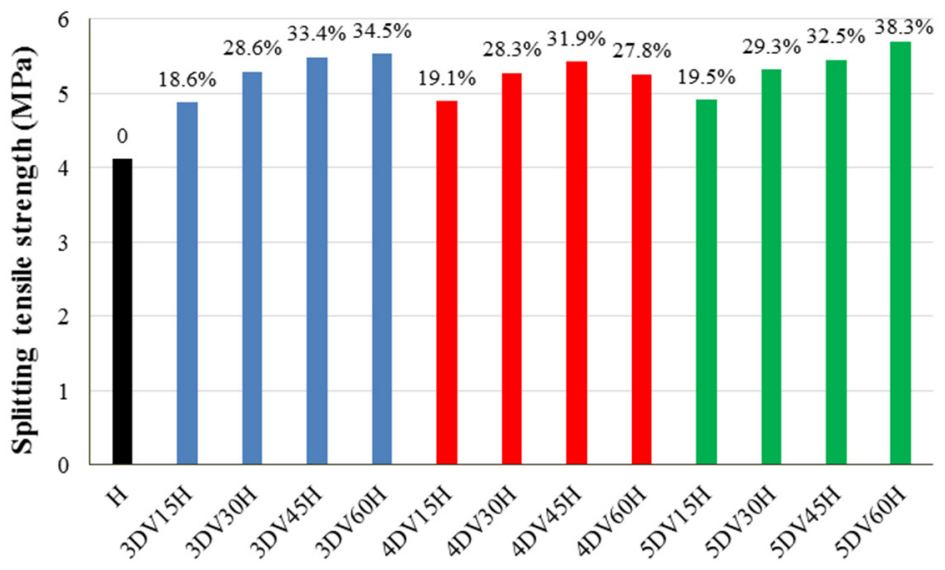

Figure 5: Splitting tensile strength of concretes.

\subsection{Limit of proportionality and fracture parameters}

The flexural tensile strength tests were performed according to TS EN 14651 which is described in Section 3. Load-displacement curves were obtained from these tests. Tests were stopped at $5 \mathrm{~mm}$ displacement. Load-displacement curves for 3D, 4D and 5D fibres in different fibre contents are given in Figure 6.

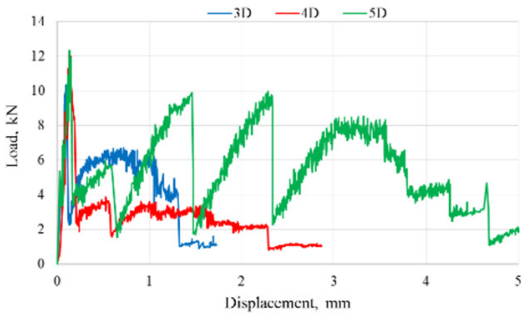

(a) $\mathrm{V}_{\mathrm{f}}=15 \mathrm{~kg} / \mathrm{m}^{3}$

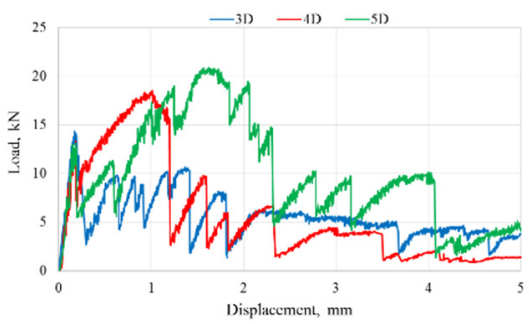

(c) $V_{\mathrm{f}}=45 \mathrm{~kg} / \mathrm{m}^{3}$

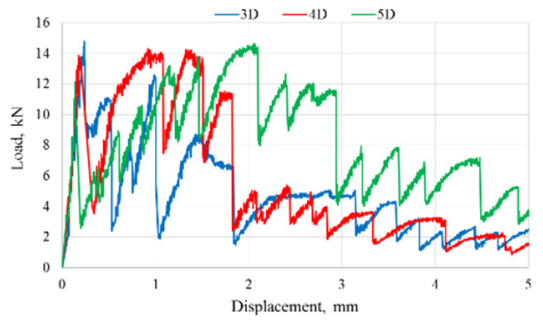

(b) $V_{\mathrm{f}}=30 \mathrm{~kg} / \mathrm{m}^{3}$

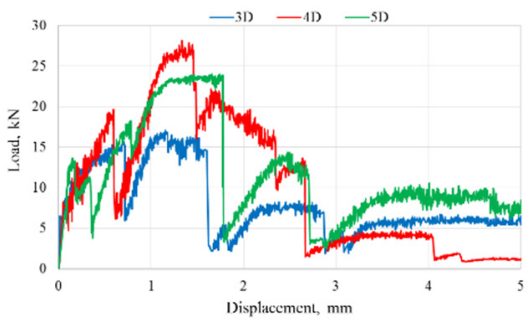

(d) $V_{f}=60 \mathrm{~kg} / \mathrm{m}^{3}$

Figure 6: Load versus displacement curves. 
Different post-cracking behaviours were observed for types of hooked-end. Peak loads were obtained higher than first crack loads in the mixtures consisting 4D and 5D types of fibre and high amount of fibre. After peak loads, load values did not decrease dramatically and could be increase at $60 \mathrm{~kg} / \mathrm{m}^{3}$ fibre content. In low fibre $\left(\mathrm{V}_{\mathrm{f}}=15 \mathrm{~kg} / \mathrm{m}^{3}\right)$ content mixtures, 3D and 4D type hooked-ended fibres were broken at early displacement.

LOP values can be seen in Figure 7. Generally, LOPs were increased with increasing fibre content. LOP values were about 4.0-4.5 $\mathrm{MPa}$ in mixtures consisting of fibres exclude 3DV15. However, any significant effect of type of hooked-end was not observed on LOP.

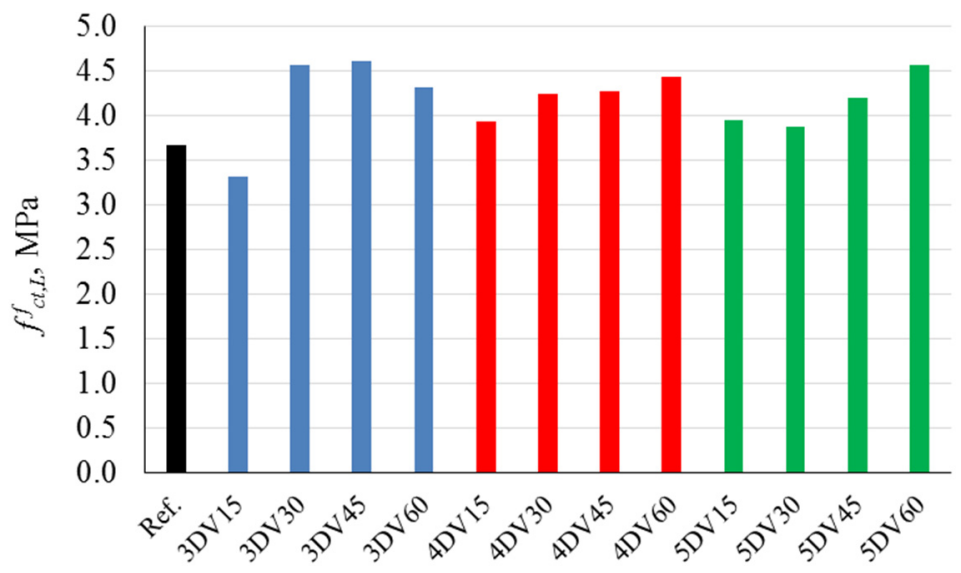

Figure 7: LOP values.

Fracture energies and characteristic lengths were calculated according to Equations (2) and (3), respectively. Fracture energy and characteristic length values of mixtures are given in Figures 8 and 9, respectively. Fracture energies and characteristic lengths of mixtures were increased with increasing of fibre content and also type of hooked end of steel fibres affected fracture parameters. 5D type hooked-ended fibres were the most effective with respect to both of fracture energy and characteristic length. 3D and 4D types hooked-end fibres were exhibited equal performance in both of fracture energy and characteristic length. But, 4D fibres were exhibited better performance than 3D fibres in mixture consisting $60 \mathrm{~kg} / \mathrm{m}^{3}$ fibre. 
274 High Performance and Optimum Design of Structures and Materials II

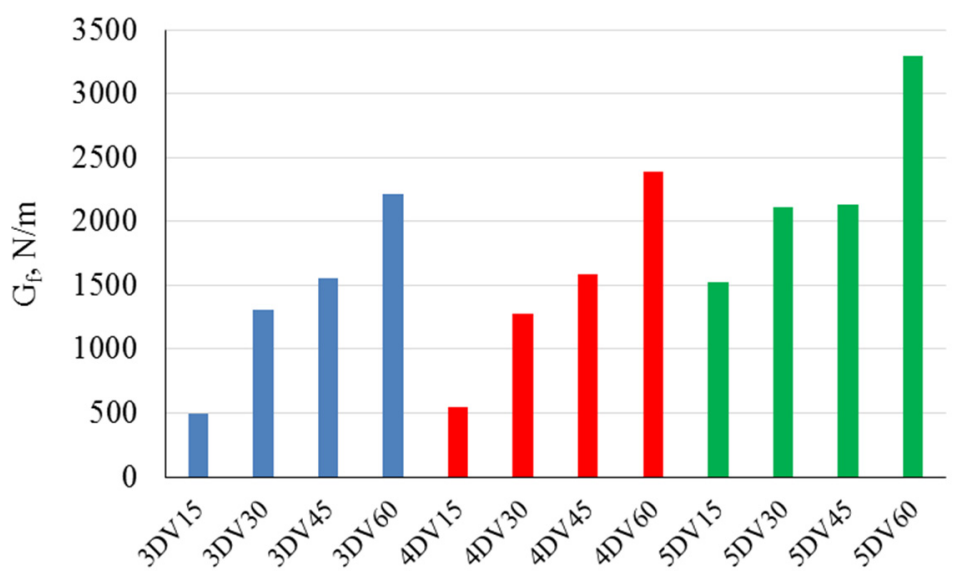

Figure 8: Fracture energy values.

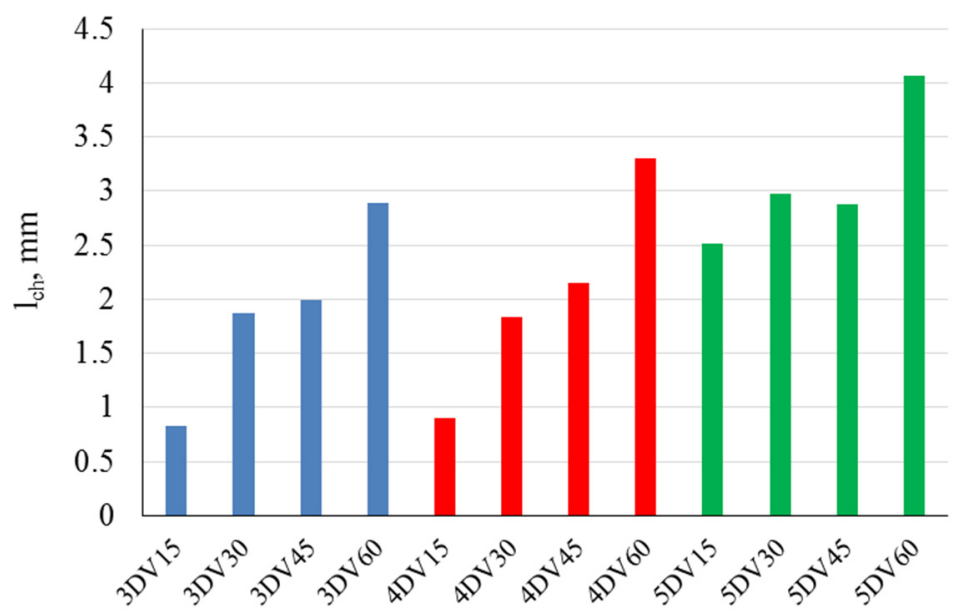

Figure 9: Characteristic length of mixtures.

\section{Conclusions}

It has been seen that type of hooked and was a significant effect on the properties of SFRC. Further conclusions from the present study can be stated as below;

- Fresh concrete properties were not affected by the type of hooked-end. However, slump values were decreased and Vebe times were increased with increasing fibre content. 
- Hooked-end type and amount of steel fibres did not affect the compressive strength and modulus of elasticity, significantly. Splitting tensile strength of concretes were increased with increasing of fibre content. Nevertheless, effect of type of hooked-end were not observed on the splitting tensile strength. 5D hooked-ended steel fibres were increased up the splitting tensile strength as $38.3 \%$.

- Post cracking behaviours were affected by the amount and type of hookedend of fibres. Also, effect of fibre strength can be take in to consideration at the softening part.

- $\quad$ The LOP and fracture parameters were increased with increasing of fibre content. The effect of type of hooked-end was not observed on the LOP, however 5D type hooked-ended fibres were exhibited better performance on the fracture parameters. About $3300 \mathrm{~N} / \mathrm{m}\left(\mathrm{J} / \mathrm{m}^{2}\right)$ fracture energy was obtained by using $5 \mathrm{D}$ type steel fibres.

\section{Acknowledgement}

This study has been completed under the project (No: $2015 \mathrm{FBE} / \mathrm{T} 212$ ) of the Bozok University, Institute of Science and Technology.

\section{References}

[1] Shah, A. A. \& Ribakov, Y., Recent trends in steel fibered high-strength concrete. Materials and Design, 32 (8-9), pp. 4122-4151, 2011.

[2] Taşdemir, M. A., Şengül, Ö., Şamhal, E. \& Yerlikaya, M., Endüstriyel Zemin Betonlarl, Chamber of Civil Engineers publication, 450 pp., 2006.

[3] Walraven, J. High performance fiber reinforced concrete: progress in knowledge and design codes. Materials and Structures, 42(9), 2009.

[4] Kaïkea, A., Achoura, D., Duplan, F., \& Rizzuti, L., Effect of mineral admixtures and steel fiber volume contents on the behavior of high performance fiber reinforced concrete. Materials \& Design, 63, pp. 493499, 2014.

[5] Soltanzadeh, F., Barros, J.A.O., \& Santos, R.F.C., High performance fiber reinforced concrete for the shear reinforcement: Experimental and numerical research. Construction and Building Materials, 77, pp. 94-109, 2015.

[6] Alberti, M. G., Enfedaque, A., Galvez, J. C., Canovas, M. F. \& Osorio, I. R., Polyolefin fiber-reinforced concrete enhanced with steel-hooked fibers in low proportions. Materials and Design, 60, pp. 57-65, 2014.

[7] Zile, E. \& Zile, O., Effect of the fiber geometry on the pullout response of mechanically deformed steel fibers. Cement and Concrete Research, 44, pp. 18-24, 2013.

[8] Banthia, N. \& Trottier, J., Concrete reinforced with deformed steel fibers, part I: bond-slip mechanisms. ACI Materials Journal, (91), pp. 435-446, 1994. 
[9] Robins, P., Austin, S. \& Jones, P., Pull-out behaviour of hooked steel fibres. Materials and Structures, 35 (251), pp. 434-442, 2002.

[10] Cunha, V. M. C. F., Barros, J.A.O. \& Sena-Cruz, J. M., Pullout behavior of steel fibers in self-compacting concrete. Journal of Materials in Civil Engineering, 22 (1), pp. 1-9, 2010.

[11] Feng, J., Sun, W. W., Wang, X. M., \& Shi, X. Y., Mechanical analyses of hooked fiber pullout performance in ultra-high-performance concrete. Construction and Building Materials, 69, pp. 403-410, 2014.

[12] RILEM 50-FMC committee fracture mechanics of concrete, Draft Recommendation, Materials and structures, 18 (106), pp. 285-290, 1985.

[13] Hillerborg A, Modeer M, \& Peterson P.E., Analysis of crack formation and crack growths in concrete by means of fracture mechanics and finite elements. Cement and Concrete Research, 6, pp. 773-782, 1976. 